Please do not remove this page

RMIT

UNIVERSITY

\title{
Post occupancy evaluation of buildings in a zero carbon city
}

Kansara, T; Ridley, Ian

https://researchrepository.rmit.edu.au/esploro/outputs/9921858478801341/filesAndLinks?institution=61RMIT_INST\&index=null

Kansara, T., \& Ridley, I. (2012). Post occupancy evaluation of buildings in a zero carbon city. Global Conference on Renewables and Energy Efficiency for Desert Regions, 5(1), $23-25$.

https://doi.org/10.1016/j.scs.2012.05.010

Document Version: Accepted Manuscript

Published Version: https://doi.org/10.1016/j.scs.2012.05.010

Repository homepage: https://researchrepository.rmit.edu.au

(c) 2012 Elsevier Ltd. All rights reserved

Downloaded On 2023/04/26 21:12:36 +1000

Please do not remove this page 
Thank you for downloading this document from the RMIT Research Repository.

The RMIT Research Repository is an open access database showcasing the research outputs of RMIT University researchers.

RMIT Research Repository: http://researchbank.rmit.edu.au/

\section{Citation:}

Kansara, T and Ridley, I 2012, 'Post occupancy evaluation of buildings in a zero carbon city', Global Conference on Renewables and Energy Efficiency for Desert Regions, vol. 5, no. 1 , pp. 23-25.

See this record in the RMIT Research Repository at:

http://researchbank.rmit.edu.au/view/rmit:19949

Version: Accepted Manuscript

Copyright Statement: (c) 2012 Elsevier Ltd. All rights reserved

Link to Published Version:

http://dx.doi.org/10.1016/j.scs.2012.05.010

\section{PLEASE DO NOT REMOVE THIS PAGE}




\title{
Post Occupancy Evaluation of buildings in a Zero Carbon City
}

\author{
T. Kansara ${ }^{1}$, I. Ridley ${ }^{2}$, H. Arafat ${ }^{3}$, R. Reynolds ${ }^{4}$ \\ ${ }^{1}$ Bartlett School of Graduate Studies, University College London, UK, E-mail: tia.kansara.10@ucl.ac.uk \\ ${ }^{2}$ Bartlett School of Graduate Studies, University College London, UK, E-mail: i.ridley@ucl.ac.uk \\ ${ }^{3}$ Masdar Institute of Science and Technology, Abu Dhabi, UAE' E-mail: harafat@masdar.ac.ae \\ ${ }^{4}$ Masdar City, Abu Dhabi, E-mail: rreynolds@masdar.ae
}

\begin{abstract}
This paper presents a methodology to monitor the performance of buildings in a Zero Carbon City from the occupant perspective. Masdar City in Abu Dhabi is hailed as the World's pioneering Zero Carbon Zero Waste city. The initial phase of construction is complete and the first students have moved into the residential quarters of the Masdar Institute of Science and Technology (MIST) in September 2010. Although the study monitors both Carbon and Waste, this paper outlines a Post Occupancy Evaluation (POE) to assess the resident's satisfaction and building performance at MIST. The research focuses on the role that user behaviour and satisfaction plays on energy efficiency. It is hoped that such an approach will allow building performance to be normalized for user behaviour and to examine how best to commission, explain and handover complex low energy developments to new residents. It is hoped that the residents' reaction and adaptation to the first Zero Carbon Zero Waste city will provide valuable insights that can be applied to future low energy developments.
\end{abstract}

\section{MASDAR CITY}

Masdar City is an initiative conceived in 2006 by the Abu Dhabi Future Energy Company (ADFEC). This is a subsidiary of Mubadala Property Holdings owned by the government.

The vision for Masdar is to follow the recommendation of the Emirate's economic development goals to secure a testbed of renewable energy and sustainable technologies. Since inception, the Abu Dhabi - Urban Planning Council (UPC) has produced recommendations for the local construction industry. Two key initiatives are Estidama, the sustainability department at UPC and the Pearl Rating System (PRS) to legislate future Low-Carbon build.

One of the many aspirations of Dr Sultan Ahmed al-Jaber CEO of the project is to create a sustainable community adopting an environmentally friendly lifestyle aided by the application of technology in the built environment. The aims and aspirations can be summarised by the following key benchmarks:

- Net zero Carbon emissions zone, and improved air quality inside and outside buildings.

- $\quad 80 \%$ Reduction in energy consumption from Abu Dhabi "Business as Usual” baseline.

The aim of this research which forms the basis of a $\mathrm{PhD}$ study, is to examine the role played by resident behaviour in achieving these benchmarks, focussing on Phase 1a (MIST) within the Masdar City development. MIST is an independent, research-driven graduate institute developed with the ongoing support and cooperation of Massachusetts Institute of Technology (MIT).

This paper outlines a study of Post Occupancy Evaluation with a view to monitoring energy. This assesses the residents' satisfaction with the building performance, comparing the results to the initial benchmarks set for Masdar.

\subsection{POST OCCUPANCY EVALUATION}

POE is an "evaluation of buildings in a systematic and rigorous manner after they have been built and occupied"
(Preiser 1995) [1]. It is a system of analysis which monitors and measures the performance of a building using data gathered from environmental, social and energy monitoring. The method includes the use of surveys and questionnaires as well as technical monitoring to understand the reality of the buildings' performance once occupied.

In September 2010 the UPC launched the Pearl Rating System (PRS) where all buildings must adhere to the threepart process of creating a more carbon-efficient build. The three key areas include: Design; Construction; and Post Occupancy. This mandatory initiative is the first in the Middle East run by government to educate and bring awareness to all areas of the construction industry. The PRS aims to introduce an assessment of buildings two years after occupation. This is a timely and pioneering act by the Abu Dhabi government to reduce their per capita energy consumption. Some POE studies have been carried out in educational buildings in the UAE (Gabr, H. \& Al-Sallal, 2003) [2]. A full POE of MIST will provide a detailed data set for comparison with other regional developments.

How residents respond to socio-technical energy conservation initiatives can help to deconstruct the original design assumptions made by the designers. Stage $M$ from The Royal Institute of British Architects 'Plan of Work', (RIBA 1973) [3] mentions a need for architects to close the loop once a building is constructed: "For projects to be sustainable, the operational and decommissioning phases need to be separately identified and planned for by the client”. The client holds the responsibility to maintain the building, which rests on the client having suitable briefing with regards to the technology and user satisfaction of the building.

Stakeholders of a construction project (Designers, Managers, Government and Users) have a variety of methods to communicate their intentions during the project. The following figure outlines the feedback linkages between stakeholders and the proposed POE methodology, leading to the application of lessons learned for future developments. 


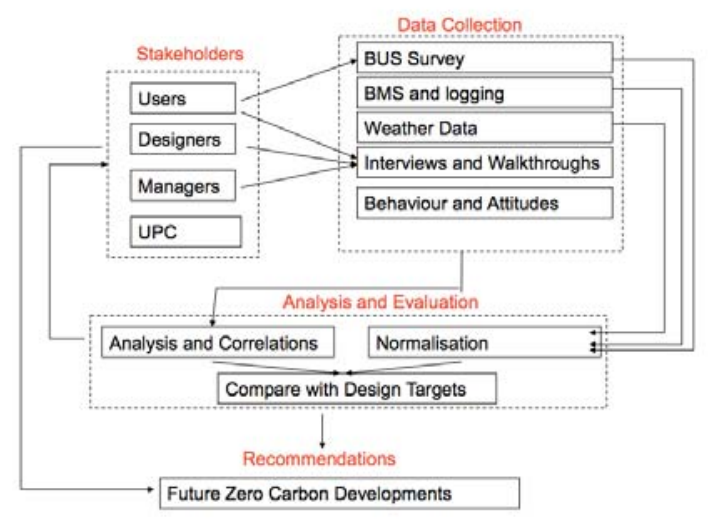

Fig 1: Schematic of Methodology

Typically, POE studies (Bordass and Leaman 2005) [4] have found that "designers, builders and sometimes even procuring clients do not engage closely with the performance of the buildings they have created. Hence, low-level, chronic problems tend to persist, innovations miss their targets, and true successes may be overlooked.”

\subsection{Why POE at MIST?}

At MIST the student residences and non-domestic buildings (e.g., Labs and Facilities) aim to achieve very low energy consumption. They are not, however, rated according to any of the regular rating systems: Leadership in Energy and Environmental Design (LEED) or Building Research Establishment Environmental Assessment Method (BREEAM). ESTIDAMA was not established at the time Masdar was conceived.

The success or failure of Masdar City will ultimately rest on a wide variety of indicators: Technical, Economic, Ecological and Social. The use of POE, particularly to systematically and accurately provide hard evidence on the performance of the buildings and the experiences of the occupants will play a valuable role in the evaluation of Masdar City in comparison to other energy efficient developments in the region.

The Masdar Case study poses a challenge to the built environment research community, namely the development of a POE strategy that is applicable and appropriate to a Zero Carbon City, where wider ecological and sustainability issues need to be addressed.

The key lessons learned from 40 years of POE, and suggestions for the future direction of research in this area have been recently summarised (Leaman et. al. 2010)[5]. In a recent review article of the use and development of POE in the residential sector (Vale 2010) [6], it is argued that: "Postoccupancy evaluation (POE) could have a significant role in the lowering of environmental impacts, but the framing of domestic POE must embrace a rating of the occupants' behaviour. A key challenge is to provide indicators not only on technical performance and usability, but also on user behaviours.” Suggested metrics and indicators to be included within POE are: Resource use per person; Waste production; Transport; Income; Home productivity; and Community involvement. An example of POE study applied to a residential development designed to be carbon neutral, is that carried out at BedZed in the UK, (Hodge et al 2009) [7], which examined performance of the Home, Food, Travel and Transport, Shelter and Thermal Comfort, Goods and Services, Waste, Community and Amenities.

POE studies repeatedly report on the importance of occupant behaviour on the performance of low energy buildings. A study of a university building, (Browne and Frame, 1999) [8], found that electricity consumption was 2.5 times higher than expected, with the behaviour and education of the occupants being seen as an important factor in this under performance, leading the authors of the study to propose that "green buildings need green occupants", In the residential sector, a study of low energy dwellings in the UK, (Gill et al 2010) [9], found that behaviour accounted for 51\%, $37 \%$, and $11 \%$ of the variance in heat, electricity, and water consumption, respectively, between dwellings. There is some evidence, (Deuble and de Dear 2010) [10] that "green occupants” who have a predisposition towards environmental issues, will be more forgiving and tolerant attitude to the performance of a building

These observations are particularly relevant to the use and design of POE for MIST. The methodology to be developed at MIST seeks to capture and investigate the role of occupant behaviour on the performance of MIST buildings and their role in achieving carbon and waste neutrality.

\section{Methodology}

The following methodology is being developed for application at MIST for the Zero Carbon aspect of the City, and aims to follow, where possible, guidelines and standard methods developed for the Building Performance Evaluation programme of the Technology Strategy Board (TSB). (Stevenson et al 2010), [11]

The study will be applied to the 100 postgraduate student residents at MIST. The indicators used at MIST include: Induction/Understanding; Satisfaction; Comfort; Control; Energy Audit of home; Realisation of design intentions; Resource use per person; and Waste production.

\subsection{Occupant Survey}

The Occupant Survey to be used is The Building Use Survey (BUS). Building Use Studies developed the BUS Survey between 1985-2008. In 2008 ARUP adopted the BUS Survey and renamed it ARUP Appraise. The methodology and philosophy of BUS is described in the ARUP journal, (Leaman 2010) [12]. The BUS questionnaire is based on the Probe questionnaire and has over thirty years of experience behind it. The residents will be given the questionnaire six months after occupation. An additional standardised survey will be used to measure the health and wellbeing of occupants. The Short Form SF- 36v2, General Health Questionnaire GHQ-12, Index of Health-Related Quality of Life, and EuroQuol5D are integrated into a questionnaire to gage the level of health of occupants.

\subsection{Energy and Environmental logging}

The energy consumption of the MIST buildings is to be logged and recorded by the BMS system. Additionally 250 
portable data loggers have been installed in MIST buildings to measure temperature and relative humidity. A two-year monitoring period, which includes a pilot project, is proposed to provide seasonal and residential variation. The first sample of students will graduate in 2011. The next batch of students will move into MIST in September 2011. Monitoring both intakes and their reactions to MIST as well as the nonresidential students will provide good grounds for comparison.

\subsection{Interviews and walk through}

Small groups of students will be interviewed whilst walking through the City. This provides the prompt for their comments and observations previously missed by the resident in the written BUS survey. A review session held to verify comments and establish priorities.

As well as the occupants a number of interviews and meetings have taken place with the designers, facility managers and building owners to identify the strategy for closing the performance gap.

\subsection{Energy Demand Response}

The POE survey will be complemented by an ongoing independent MIST Demand Response (DR) research project. DR aims to reduce occupants' electricity usage in response to power grid needs. The aim of the DR project is to implement and analyse the effect of different incentive schemes and dynamic pricing models on the load consumption behaviour of end users. The survey investigates the behaviour and attitude of MIST residents to energy use.

\section{CONCLUSION}

A Post Occupancy Evaluation (POE) to assess the resident's satisfaction and building performance at MIST, Masdar is underway. The research focuses on the role that user behaviour and satisfaction plays on energy efficiency. It is hoped that the residents' reaction and adaptation to the first Zero Carbon Zero Waste city will provide valuable insights that can be applied to future low energy developments.

\section{Acknowledgments}

The authors wish to thank Masdar City and Masdar Institute of Science and Technology for their support.

\section{References}

[1] Preiser W F.E. (1995) "Post-occupancy evaluation: how to make buildings work better", Facilities, Vol. 13 Iss: 11, pp.19 - 28

[2] Gabr, H. \& Al-Sallal, K. "School Design and Child Behavior: Post Occupancy Evaluation of Kindergartens in Al-Ain City". Proceedings of the $4^{\text {th }}$ Annual UAE University Research Conference, Al Ain, pp.ENG127-131 \& CD version, 2003.

[3] RIBA 1973. Plan of Work for Design Team Operation. RIBA Publications. ISBN 9780947877064.

[4] Bordass, B. \& Leaman, A., "Making feedback and post-occupancy evaluation routine 1: A Portfolio of feedback techniques”, Building Research \& Information Journal, 33: 4, p.347-352, 2005.

[5] Leaman, A., Stevenson, F. \& Bordass, B. "Building evaluation: practices and principles”. Building Research \& Information, 38(5), 2010.

[6] Vale, B. \& Vale, R. "Domestic energy use, lifestyles and POE: past lessons for current problems", Building Research \& Information, 38 : 5, 578 588, 2010.

[7] Hodge, J. \& Haltrecht, J., “BedZed Seven Years On”. BioRegional Solutions for Sustainability. Surrey, UK.: 43, 2009.

[8] Browne S, "Frame I. Green buildings need green occupants". Eco-Management and Auditing 6: 80-85, 1999.

[9] Gill, Z.; Tierney, M. J.; Pegg, I. and Allan, N., "Low-energy dwellings: the contribution of behaviours to actual performance", Building Research \& Information, 38: 5, 491-508, 2010.

[10] Deuble, M. \& de Dear, R. “ Green Occupants for Green Buildings: The Missing Link?”, Proceedings of Conference: Adapting to Change: New Thinking on Comfort, Cumberland Lodge, Windsor, UK, 9-11 April 2010. London: Network for Comfort and Energy Use in Buildings

[11] Stevenson, F., “Technology Strategy Board: Post-occupancy evaluation guide”, Oxford Brookes University, 2010.

[12] Leaman A, Are Buildings getting better? Arup Journal Vol 1, 2010. 